\title{
ANALYSIS OF INFLUENCE OF ACTIVATOR CONCENTRATION ON CHARACTERISTICS OF ACTIVATED CARBON FROM KETAPANG SHELL (Terminalia Catappa) BASED ON IMAGE PROCESSING METHOD
}

\author{
Herman Aldila $^{* 1)}$, Megiyo ${ }^{2)}$, Fitri Afriani ${ }^{3)}$, Yuant Tiandho ${ }^{4)}$ \\ ${ }^{1,2,3,4)}$ Department of Physics, University of Bangka Belitung \\ e-mail: hermanaldila@ubb.ac.id
}

\begin{abstract}
Activated carbon from ketapang shell (Terminalia Catappa) has been successfully synthesized using dehydration-carbonization method. Activated carbon was conducted by immersing with sulphuric acid and followed by carbonization at $600^{\circ} \mathrm{C}$ for 2 hours. Pore characteristics were determined using imageprocessing methods of activated carbon micrographs based on parameters of area and caliper length. From the area approximation method obtained that the maximum pore size estimate was 5,69 $\mu$ m at activator concentration $3 \%$ while the minimum was 4,88 $\mu$ m at activator concentration $11 \%$ activator concentration respectively. At the other hands, caliper length approximation method obtained estimation of maximum pore size that was equal to 9,09 $\mu \mathrm{m}$ at activator concentration $3 \%$ and its minimum that was equal to 7,35 $\mu \mathrm{m}$ at activator concentration 7\%. The porosity of the activated carbon from ketapang shell increased with the increase of sulfuric acid concentration and the highest value reached $24.96 \%$.
\end{abstract}

Keywords: activated carbon, activator, image processing.

\section{ANALISIS PENGARUH KONSENTRASI AKTIVATOR TERHADAP KARAKTERISTIK PORI KARBON AKTIF TEMPURUNG KETAPANG (Terminalia Catappa) BERDASARKAN METODE PENGOLAHAN CITRA}

\author{
Herman Aldila $^{* 1)}$, Megiyo $^{2)}$, Fitri Afriani ${ }^{3)}$, Yuant Tiandho ${ }^{4)}$ \\ ${ }^{1,2,3,4)}$ Jurusan Fisika, Universitas Bangka Belitung
}

\begin{abstract}
Abstrak
Karbon aktif tempurung Ketapang (Terminalia Catappa) telah berhasil disintesis dengan menggunakan metode dehidrasi-karbonisasi. Aktivasi karbon aktif dilakukan dengan menggunakan aktivator asam sulfat yang dilanjutkan dengan karbonisasi pada temperatur $600^{\circ} \mathrm{C}$ selama 2 jam. Karakteristik pori ditentukan menggunakan metode pengolahan citra dari mikrograf karbon aktif berdasarkan parameter luas area dan panjang kaliper. Berdasarkan metode pendekatan luas area diperoleh estimasi ukuran pori maksimum sebesar $5,69 \mu \mathrm{m}$ pada konsentrasi aktivator $3 \%$ dan minimum sebesar $4,88 \mu \mathrm{m}$ pada konsentrasi aktivator $11 \%$. Sedangkan dengan metode pendekatan panjang kaliper diperoleh estimasi ukuran pori maksimum sebesar $9,09 \mu \mathrm{m}$ pada konsentrasi aktivator $3 \%$ dan minimum sebesar 7,35 $\mu \mathrm{m}$ pada konsentrasi aktivator $7 \%$. Porositas karbon aktif tempurung ketapang semakin meningkat seiring dengan peningkatan konsentrasi asam sulfat dengan nilai tertinggi sebesar $24,96 \%$.
\end{abstract}

Kata kunci: aktivator, analisis citra, karbon aktif.

${ }^{* 1)}$ Komunikasi Penulis 


\section{Pendahuluan}

Tanaman ketapang (Terminalia Catappa) banyak ditemukan disekitar kampus Universitas Bangka Belitung sebagai pohon peneduh disepanjang jalan maupun area parkir kampus. Hampir setiap hari dapat dijumpai buah ketapang yang berguguran dan selalu dibuang sebagai sampah dalam jumlah besar. Salah satu upaya agar sampah ketapang yang murah dan berlimpah ini dapat menjadi produk yang berguna dan memiliki nilai ekonomis dengan dibuat menjadi material karbon aktif. Konversi sampah ketapang menjadi karbon aktif diharapkan dapat mengatasi permasala han sampah yang disebabkan oleh ketapang. Disisi lain dengan adanya konversi ini dapat diperoleh suatu produk yang memiliki nilai guna dan ekonomis tinggi karena karbon aktif banyak digunakan dalam berbagai bidang industri secara luas. Beberapa penggunaan karbon aktif antara lain sebagai adsorben, katalisator, elektroda dan lain sebagainya. Tantangan utama dalam sintesis karbon aktif adalah mendapatkan produk yang sangat spesifik sesuai dengan kegunaannya. Sintesis karbon aktif tempurung ketapang telah dilaku kan oleh beberapa peneliti sebelumnya (Surest, et al., 2010; Awitdrus, et al., 2016; Megiyo, et al., 2017). Akan tetapi belum ada yang menganalisis pengaruh konsentrasi aktivator terhadap karakteristik pori karbon aktif tempurung ketapang.

Karakteristik pori merupakan bagian terpenting dalam menentukan kualitas suatu karbon aktif. Karakteristik pori suatu karbon aktif meliputi: ukuran, bentuk geometris, distribusi, porositas dan lain sebagainya. Beberapa metode yang telah digunakan untuk menentukan karakteristik pori antara lain melalui metode pengukuran langsung metode Brunauer, Emmet, and Teller (Goodman, et al., 2012) dan metode Archimedes (Moradi, et al., 2014) serta metode pengolahan citra mikrograf (Tiandho, 2017; Aldila, et al., 2017). Metode pengolahan citra lebih efisien daripada dengan menggunakan metode pengukuran langsung ditinjau dari aspek reproduktivitas, ekonomi, kesederhanaan, dan fleksibilitasnya. Hal ini didukung dengan pengembangan instrumen pengukuran morfologi permukaan material dalam bentuk digital yang semakin maju (Tiandho, 2017). Metode pengolahan citra telah diaplikasikan dalam berbagai bidang diantaranya untuk penentuan karakteristik pori (Tiandho, 2017; Aldila, et al., 2017), klasifikasi sel darah merah (Jambhekar, 2011), menghitung luas inti eritrosit (Rifano, 2014), pendeteksi formalin pada tahu (Hidayat.A, et al., 2013), penentuan porositas plasmasprayed coatings (Du, et al., 2005) dan sebagainya.

Melalui penelitian ini dianalisis pengaruh konsentrasi aktivator terhadap karakteristik pori yang meliputi: ukuran, distribusi dan porositas pori karbon aktif tempurung ketapang (Terminalia Catappa) dengan metode analisis citra yang didasarkan pada parameter luas area dan panjang kaliper.

\section{Bahan dan Metode}

Bahan utama yang digunakan dalam penelitian ini adalah tempurung ketapang (Terminalia Catappa) yang diperoleh dari kampus Universitas Bangka Belitung, aktivator asam sulfat $\left(\mathrm{H}_{2} \mathrm{SO}_{4}\right)$, dan air suling.

Peralatan yang digunakan dalam sintesis karbon aktif berbasis tempurung ketapang terdiri dari tungku pembakaran, mortar, hot plate stirrer ciramec, magnetic stirrer bar, crucible porseline, ayakan 200 mesh, $\mathrm{pH}$ meter, kertas saring, gelas ukur dan gelas kimia. Alat untuk mengkarakterisasi sampel digunakan peralatan SEM Merk FEI tipe Inspect S50 serta perangkat lunak ImageJ.

Sintesis diawali dengan melakukan preparasi tempurung ketapang yang meliputi dua tahap yaitu proses pembersihan dan proses pengeringan. Tempurung ketapang kering kemudian dibakar dalam tungku pembakaran hingga menjadi arang (karbon). Arang tempurung ketapang kemudian digerus dengan menggunakan mortar kemudian ditapih dengan menggunakan ayakan ukuran 200 mesh. Serbuk karbon berukuran 200 mesh kemudian direndam dengan asam sulfat dengan variasi konsentrasi masing-masing 3\%, 7\% dan $11 \%$ selama satu hari dengan rasio 1 gr karbon : 4 $\mathrm{mL}$ asam sulfat. Hasil rendaman ketiga sampel karbon dipisahkan dengan filtratnya lalu diaktivasi dengan cara dipanaskan dalam furnace pada suhu $600^{\circ} \mathrm{C}$ selama 2 jam. Karbon hasil aktivasi dicuci dengan mengguna kan air suling hingga mencapai $\mathrm{pH}$ netral 
kemudian dikeringkan dengan menggunakan oven.

Identifikasi mikrostruktur karbon aktif hasil sintesis dilakukan dengan menggunakan Scanning Electron Microscope (SEM). Sedangkan untuk menentukan karakteristik pori meliputi: estimasi ukuran, distribusi ukuran dan porositas pori digunakan metode pengolahan citra dengan perangkat lunak ImageJ berdasarkan parameter luas area dan panjang kaliper dari mikrograf sampel karbon aktif tempurung ketapang yang telah disintesis.

\section{Hasil dan Pembahasan}

Mikrograf karbon aktif tempurung ketapang (Terminalia Catappa) dan proses pengolahan citra pada mikrograf ditampilkan pada Gambar 1. Proses pengolahan citra pada makalah ini meliputi proses binerisasi dan proses segmentasi. Proses binerisasi bertujuan untuk memperjelas perbedaan antara pori dan matriks karbon aktif dengan menggunakan pola gelap-terang.

A. Mikrograf Karbon Aktif Tempurung Ketapang

Konsentrasi Aktivator 3\%

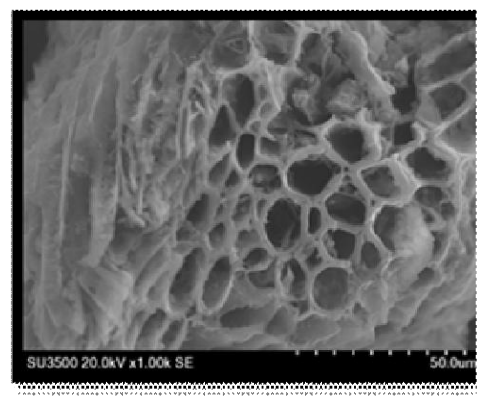

Konsentrasi Aktivator 7\%

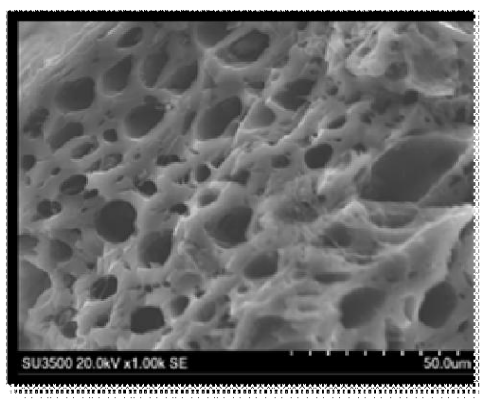

Konsentrasi Aktivator 11\%

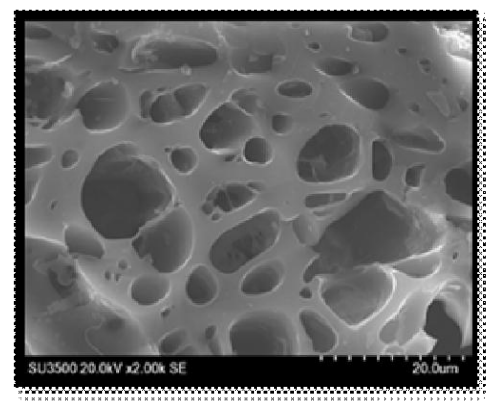

B. Proses Binerisasi pada Mikrograf
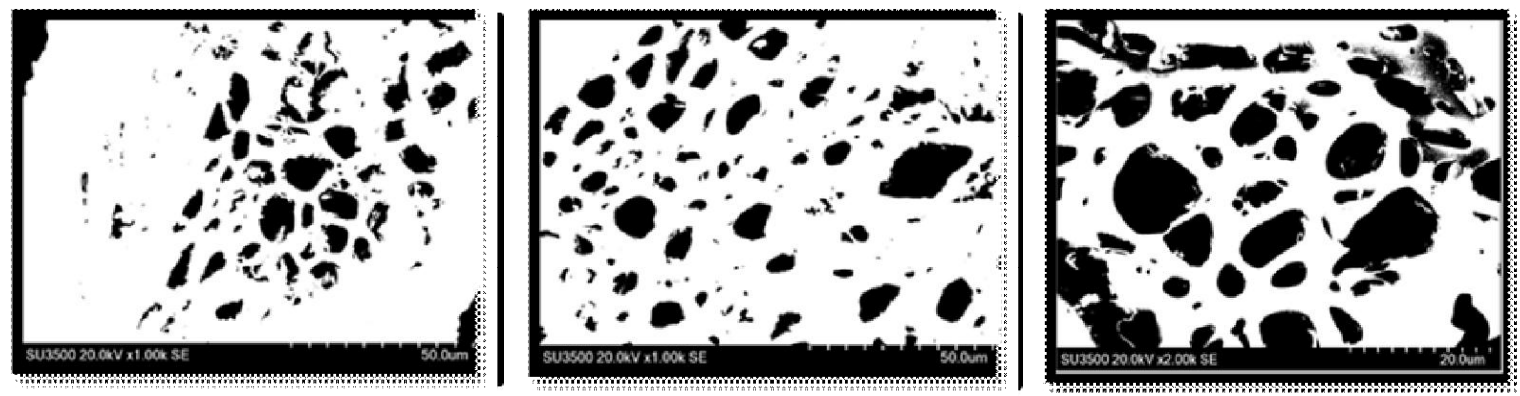

C. Proses Segmentasi pada Mikrograf
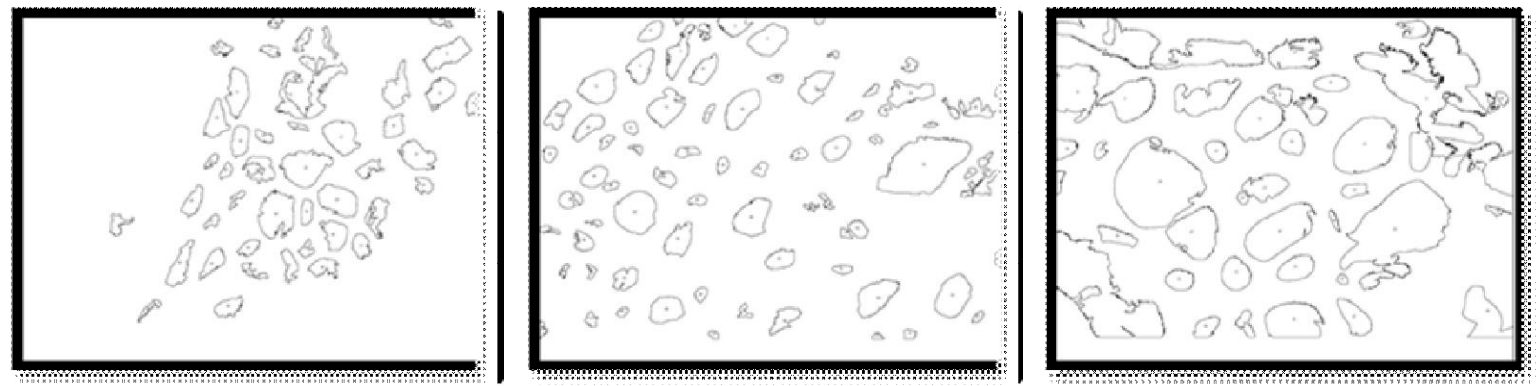

Gambar 1. Mikrograf karbon aktif tempurung ketapang, proses binerisasi dan segmentasi. 
Setelah dilakukan proses binerisasi, pori terlihat lebih gelap sedangkan matriks terlihat lebih terang sehingga perbedaan pori dan matriks tampak semakin jelas. Proses segmentasi adalah proses mempartisi citra digital menjadi beberapa segmen untuk menyederhanakan penyajian data citra ke sesuatu yang lebih bermakna sehingga dapat dianalisis. Pada proses ini dilakukan pendeteksian pori sesuai dengan geometris perimeter pori yang terdeteksi. Selanjutnya dilakukan perhitungan perimeter pori yang terdeteksi pada masing-masing mikrograf. Dalam hal ini perimeter merupakan panjang garis batas antara masing-masing pori dengan matriks yang dihitung berdasarkan jumlah pixel yang terdapat pada daerah tersebut. Sedangkan area merupakan jumlah pixel penyusun dalam suatu pori yang terdeteksi. Mikrograf yang digunakan dalam makalah ini memiliki faktor konversi skala piksel untuk mikrograf konsentrasi aktivator 3\% dan 7\% sebesar $10,10 \mu \mathrm{m} /$ piksel dan untuk mikrograf konsentrasi aktivator $11 \%$ sebesar 20,25 $\mu \mathrm{m} /$ piksel.

Metode pendekatan penentuan estimasi ukuran pori menggunakan perangkat lunak ImageJ pada makalah ini didasarkan pada dua parameter yaitu luas area dan panjang kaliper. Penentuan estimasi ukuran pori menggunakan parameter luas area didasarkan pada jumlah pixel penyusun dalam suatu pori yang terdeteksi. Selanjutnya geometris pori yang terdeteksi didekati dengan bentuk geometris lingkaran. Penentuan diameter pori (d) berdasarkan parameter luas area digunakan persamaan:

$$
d=2 \sqrt{\frac{A}{\pi}}
$$

dengan A adalah luas area pori dan $\pi$ adalah konstanta tak berdimensi yang nilainya 3,14.

Data hasil analisis estimasi ukuran pori berdasarkan parameter luas area disajikan pada Tabel 1. Dapat diamati bahwa karbon aktif tempurung ketapang yang berhasil disintesis memiliki estimasi ukuran pori yang masuk dalam kategori makropori (IUPAC, 1972). Sampel yang menggunakan konsentrasi aktivator asam sulfat 3\% memiliki estimasi ukuran pori (diameter) rata-rata terbesar dari sampel lainnya yaitu sebesar 5,69 $\mu \mathrm{m}$. Sedangkan ukuran pori (diameter) rata-rata terkecil terdapat pada penggunaan konsentrasi aktivator $11 \%$ yaitu sebesar $4,88 \mu \mathrm{m}$.

Tabel 1. Hasil analisis estimasi ukuran pori berdasarkan parameter luas area

\begin{tabular}{lccc}
\hline \multicolumn{1}{c}{ Parameter } & \multicolumn{3}{c}{ Konsentrasi Aktivator } \\
\cline { 2 - 4 } STDEV & $3 \%$ & $7 \%$ & $11 \%$ \\
\hline $\begin{array}{l}\text { Estimasi Ukuran } \\
\text { Pori Rata-rata } \\
(\mu \mathrm{m})\end{array}$ & 5,69 & 4,90 & 4,88 \\
STDEV & 2,21 & 2,88 & 3,14 \\
Sphericity & 0,58 & 0,67 & 0,59 \\
\hline
\end{tabular}

Ditinjau dari nilai standar deviasi (STDEV) pada masing-masing sampel meningkat seiring dengan meningkatnya konsentrasi aktivator. Pada sampel yang menggunakan konsentrasi aktivator $3 \%$ memiliki nilai standar deviasi paling rendah yaitu 2,21 dan secara statistik menyebabkan estimasi ukuran pori (diameter) rata-rata pada sampel menjadi paling besar dari sampel yang menggunakan konsentrasi aktivator $7 \%$ dan $11 \%$.

Berdasarkan Tabel 1. terdapat data sphericity yang mendeskripsikan geometris pori yang terdeteksi. Sphericity memiliki rentang 0 hingga 1 dimana jika sphericity bernilai satu maka pori berbentuk lingkaran. Semakin besar nilai sphericity (mendekati satu) maka geometris pori akan mendekati geometris lingkaran. Nilai sphericity sebanding dengan akar kuadrat jumlah pixel dalam pori (luas area) dan berbanding terbalik dengan jumlah pixel pada daerah batas antara pori dan matriks (panjang perimeter). Penentuan nilai sphericity ( $\sigma)$ memenuhi persamaan:

$$
\sigma=\frac{2}{P} \sqrt{\pi A}
$$

dengan $\mathrm{A}$ adalah luas area pori, $\mathrm{P}$ adalah panjang perimeter dan $\pi$ adalah konstanta tak berdimensi yang nilainya 3,14 . 


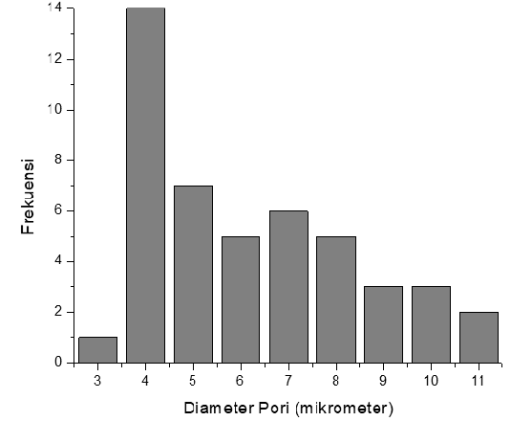

(a)

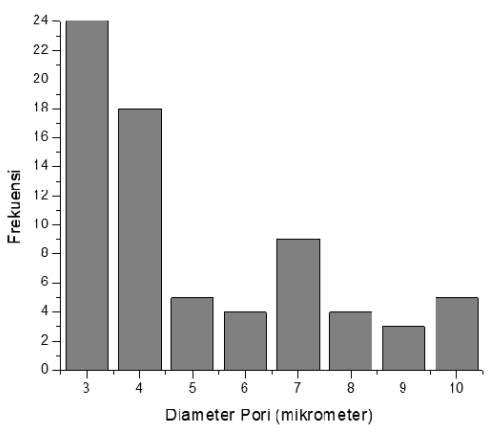

(b)

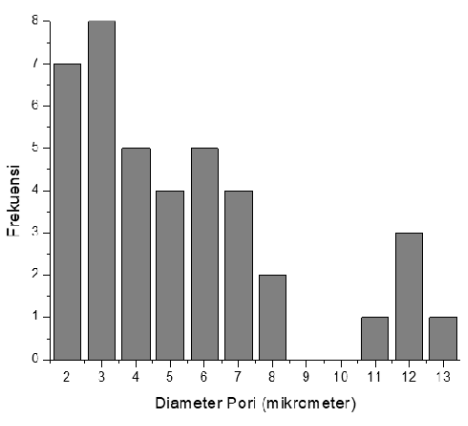

(c)

Gambar 2. Histogram distribusi estimasi ukuran pori berdasarkan parameter luas area pada konsentrasi aktivator: (a) 3\%, (b) $7 \%$ dan (c) $11 \%$.

Data sphericity untuk masing-masing sampel memiliki kisaran rentang nilai sebesar $0,58-$ 0,67 . Hal ini menunjukkan bahwa geometris pori tidak lingkaran. Nilai sphericity terbesar terdapat pada sampel yang mengguna kan konsentrasi aktivator $7 \%$ yaitu sebesar 0,67 .

Sebagai pembanding digunakan metode pendekatan penentuan estimasi ukuran pori yang didasarkan pada parameter panjang kaliper. Berbeda dengan metode pendekatan sebelumnya yang didasarkan pada geometris lingkaran, metode pendekatan panjang kaliper ini didasarkan pada panjang kaliper dari masing-masing pori yang terdeteksi. Panjang kaliper merupakan jarak terjauh antara tepitepi suatu pori. Panjang kaliper setiap pori secara otomatis telah dihitung oleh komputer apabila morfologi dari perimeter telah sesuai.

Tabel 2. Hasil analisis estimasi ukuran pori berdasarkan parameter panjang kaliper

\begin{tabular}{lccc}
\hline \multirow{2}{*}{ Parameter } & \multicolumn{3}{c}{ Konsentrasi Aktivator } \\
\cline { 2 - 4 } & $3 \%$ & $7 \%$ & $11 \%$ \\
\hline $\begin{array}{l}\text { Estimasi Ukuran } \\
\text { Pori Rata-rata }\end{array}$ & 9,09 & 7,35 & 7,45 \\
$(\mu \mathrm{m})$ & & & \\
STDEV & 3,20 & 4,13 & 5,81 \\
\hline
\end{tabular}

Estimasi ukuran pori rata-rata pada sampel konsentrasi aktivator 3\% memiliki nilai terbesar dibandingkan dengan sampel konsentrasi aktivator 7\% dan 11\% (Tabel 2). Sedangkan estimasi ukuran pori rata-rata terkecil terdapat pada sampel konsentrasi aktivator $7 \%$.
Histogram sebaran estimasi ukuran pori pada sampel (Gambar 3.) menunjukkan bahwa pola sebaran estimasi ukuran pori. Pola yang sama ditunjukkan pada metode parameter panjang kaliper bahwa nilai standar deviasi meningkat seiring dengan peningkatan konsentrasi aktivator. Akan tetapi secara rata-rata nilai standart deviasi dengan menggunakan metode panjang kaliper lebih besar daripada metode luas area. Hal ini menunjukkan bahwa pada hasil penelitian ini metode panjang kaliper akan mendeteksi ragam ukuran pori lebih banyak daripada metode luas area.

Tabel 3. Hasil analisis estimasi ukuran pori dan porositas karbon aktif tempurung ketapang

\begin{tabular}{cccc}
\hline $\begin{array}{c}\text { Konsentrasi } \\
\text { Aktivator } \\
(\%)\end{array}$ & \multicolumn{2}{c}{$\begin{array}{c}\text { Estimasi Ukuran } \\
\text { Pori }(\mu \mathrm{m})\end{array}$} & $\begin{array}{c}\text { Porositas } \\
(\%)\end{array}$ \\
\cline { 2 - 3 } & MLA & MPK & \\
\hline 3 & 5,69 & 9,09 & 5,62 \\
7 & 4,90 & 7,35 & 19,88 \\
11 & 4,88 & 7,45 & 24,96 \\
\hline
\end{tabular}

Secara ringkas hasil analisis estimasi ukuran pori dari kedua metode pendekatan yang telah dilakukan ditampilkan pada Tabel 3.

Berdasarkan data hasil analisis ukuran pori berdasarkan pada metode luas area (MLA) dan metode panjang kaliper (MPK) tersebut dapat diamati respon antara ukuran pori terhadap konsentrasi aktivator.

Pada metode pendekatan parameter luas area menunjukkan bahwa semakin besar konsentrasi aktivator asam sulfat yang digunakan maka estimasi ukuran pori akan 
semakin mengecil. Sedangkan pada metode pendekatan parameter panjang kaliper menunjukkan pola yang fluktuatif terhadap estimasi ukuran pori dimana penggunaan konsentrasi aktivator pada rentang 3\% hingga 7\% mengalami penurunan sedangkan pada rentang $7 \%$ hingga $11 \%$ mengalami kenaikan.

Estimasi ukuran pori maksimum yang diperoleh berdasarkan analisis kedua metode pendekatan tersebut tercapai pada penggunaan konsentrasi aktivator 3\% yaitu untuk metode luas area sebesar 5,69 $\mu \mathrm{m}$ dan metode panjang kaliper 9,09 $\mu \mathrm{m}$. Sedangkan estimasi ukuran pori minimum yang tercapai untuk masingmasing metode pendekatan berbeda-beda. Estimasi ukuran pori minimum untuk masingmasing metode yaitu $4,88 \mu \mathrm{m}$ untuk metode luas area pada penggunaan konsentrasi aktivator $11 \%$ dan $7,35 \mu \mathrm{m}$ untuk metode panjang kaliper pada penggunaan konsentrasi aktivator $7 \%$.

Terdapat perbedaan hasil analisis yang cukup signifikan dari penggunaan dua metode tersebut dari sisi estimasi ukuran pori karbon aktif yang terdeteksi. Hal ini dikarenakan pengambilan pendekatan geometris lingkaran pada metode luas area kurang sesuai. Nilai sphericity menunjukkan bahwa ketiga sampel memiliki nilai yang tidak sama dengan satu. Jelas hal ini menyebabkan perbedaan hasil antara kedua metode tersebut karena geometris pori tidak berupa lingkaran sempurna. Akan tetapi pola distribusi estimasi ukuran pori yang diperoleh dari kedua metode tersebut mirip. Pada konsentrasi aktivator $7 \%$ misalnya terdapat pemusatan distribusi estimasi ukuran pori pada satu ukuran walaupun ukuran yang dimaksud tidak sama persis. Ditinjau dari selisih estimasi ukuran pori hasil analisis kedua metode tersebut, nilai selisih terkecil terdapat pada sampel yang menggunakan konsentrasi aktivator 7\%. Hal ini dikarenakan pada sampel ini memiliki nilai sphericity yang paling besar dibandingkan dengan sampel yang lainnya yaitu sebesar 0,67 sehingga memungkinkan pendekatan geometris morfologi pori dalam hal ini luas area (MLK) dengan panjang kaliper (MPK) tidak jauh berbeda.

Pengaruh konsentrasi terhadap luas permukaan pori bergantung pada temperatur karbonisasi, rasio perbandingan antara aktivator terhadap karbon (arang) yang akan diaktivasi dan lama waktu perendaman karbon (arang) dengan aktivator (Kwaghger \& Ibrahim, 2013). Dalam penelitian yang dilakukan oleh Kwaghger terkait dengan optimasi sintesis karbon aktif dari tempurung biji mangga diperoleh bahwa seiring dengan peningkatan konsentrasi aktivator $\mathrm{HCl}(25 \%$; $50 \% ; 75 \%$ dan $100 \%$ ) maka luas permukaan pori juga akan semakin meningkat. Akan tetapi dalam penelitian tersebut disebutkan bahwa belum dicapai kondisi maksimum. Hal ini ditandai dengan peningkatan luas permukaan pori yang relatif cukup rendah.

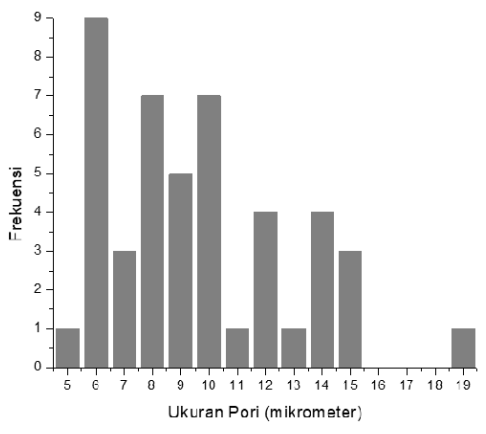

(a)

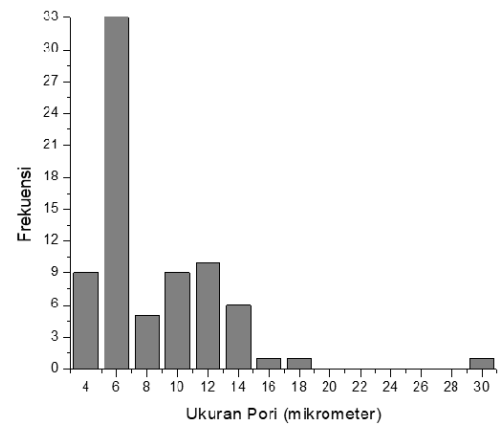

(b)

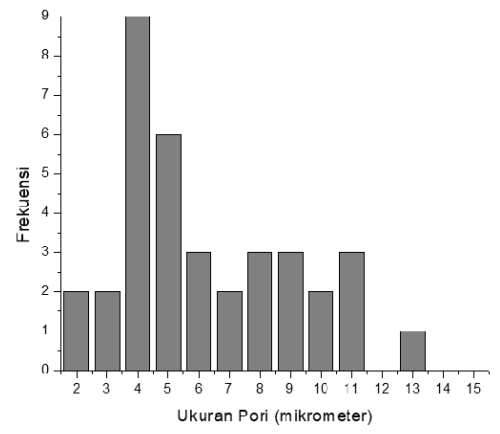

(c)

Gambar 3. Histogram distribusi estimasi ukuran pori berdasarkan parameter panjang kaliper pada konsentrasi aktivator: (a) 3\%, (b) $7 \%$ dan (c) $11 \%$. 
Disisi lain dalam penelitian yang dilakukan oleh Djeni Hendra dan Saptadi Darmawan menghasilkan hal yang sebaliknya. Peningkatan konsentrasi aktivator $\mathrm{H}_{3} \mathrm{PO}_{4}(0 \%$; 2,5\%; 5\% dan 7,5\%) dalam sintesis karbon aktif tempurung kemiri menghasilkan pola yang fluktuatif terhadap uji daya serap pada uap kloroform (Hendra \& Darmawan, 2007). Pola daya serap karbon aktif kemiri terhadap uap kloroform pada rentang $0 \%$ hingga $5 \%$ mengalami peningka tan dan pada penggunaan konsentrasi $7,5 \%$ mengalami penurunan. Dalam penelitian tersebut dijelaskan hubungan antara daya serap karbon aktif terhadap luas permukaan pori dimana semakin besar daya serapnya maka karbon aktif tersebut memiliki luas permukaan pori yang besar.

Hasil analisis ukuran pori dengan metode analisis citra pada penelitian ini dan kedua penelitian sebelumnya jelas bahwa konsentrasi aktivator tidak memiliki pola linier terhadap pembentukan luas permukaan pori maksimum. Melainkan pembentukan luas permukaan pori maksimum akan tercapai pada suatu kondisi konsentrasi aktivator tertentu (kondisi optimum). Penentuan kondisi ini akan menjadi sangat kompleks apabila terdapat variabel-varibel lain dalam proses sintesis seperti jenis bahan baku, ukuran bahan baku (powdered, granular, maupun extruded), jenis aktivator, rasio perendaman, konsentrasi aktivator, temperatur dan lama waktu karbonisasi.

Perhitungan presentase pori didasarkan pada perbedaan warna antara pori dengan matriks karbon pada proses binerisasi mikrograf. Warna pori tampak lebih gelap dibandingkan dengan warna matriks karbon aktif. Presentase pori diperoleh dari perbandingan jumlah piksel pori yang terdeteksi $\left(\mathrm{N}_{\text {gelap }}\right)$ dengan jumlah piksel total mikrograf $\left(\mathrm{N}_{\text {total }}\right)$.

$$
\% \text { Pori }=\frac{N_{\text {gelap }}}{N_{\text {total }}} \times 100 \%
$$

Porositas pori karbon aktif meningkat seiring peningkatan konsentrasi aktivator yang digunakan dengan presentase porositas terbesar 24,96\% (Tabel 3). Hal ini kemungkinan disebabkan oleh reaksi antara lignoselulosa dalam arang tempurung ketapang dengan asam sulfat sesaat setelah dicampur kan. Asam akan mengurai hemiselulosa dan lignin karena selulosa lebih tahan terhadap hidrolisis asam (Jagtoyen \& Derbyshire, 1998). Asam akan menghidrolisis rantai glikosidik pada lignoselulosa dan memutus ikatan eril eter pada lignin yang disertai oleh transformasi kimia yang menyebabkan terbentuknya pori baru (Kwaghger \& Ibrahim, 2013). Selain itu peningkatan konsentrasi asam mengakibatkan peningkatan aktivitas devola-tilisasi pada arang sehingga struktur pori awal yang sebelumnya tertutup komponen-komponen volatil akan terbuka.

\section{Kesimpulan dan Saran}

Penentuan estimasi ukuran pori menggunakan metode pengolahan citra dengan parameter luas area dan panjang kaliper menghasilkan estimasi ukuran pori karbon aktif tempurung ketapang rata-rata yang berbeda. Pendekatan geometris lingkaran pada metode pendekatan luas area kurang tepat dikarenakan nilai sphericity yang diperoleh tidak sama dengan satu. Nilai sphericity maksimum terdapat pada sampel dengan konsentrasi aktivator 7\% yaitu sebesar 0,67. Konsentrasi aktivator asam sulfat berpengaruh terhadap ukuran pori karbon aktif tempurung ketapang (Terminalia Catappa). Analisis estimasi ukuran pori dengan metode pendekatan luas area diperoleh estimasi ukuran pori maksimum sebesar 5,69 $\mu \mathrm{m}$ pada konsentrasi aktivator $3 \%$ dan minimum sebesar 4,88 $\mu \mathrm{m}$ pada konsentrasi aktivator $11 \%$. Sedangkan dengan metode pendekatan panjang kaliper diperoleh estimasi ukuran pori maksimum sebesar 9,09 $\mu \mathrm{m}$ pada konsentrasi aktivator 3\% dan minimum sebesar 7,35 $\mu \mathrm{m}$ pada konsentrasi aktivator 7\%. Estimasi ukuran pori karbon aktif tempurung ketapang (Terminalia Catappa) yang diperoleh termasuk dalam kategori makropori. Porositas pori karbon aktif meningkat seiring dengan peningkatan konsentrasi aktivator dengan persentase tertinggi sebesar $24,96 \%$.

\section{Daftar Pustaka}

Adel, A., Abd El-Wahab, Z., Ibrahim, A., \& Al-Shemy, M., 2010. Characterization 
of Microcrystalline Cellulose Prepared from Lignocellulosic Materials. Bioresource Technology, Volume 101, pp. 4446-4455.

Aldila, H., Indriawati, A., Tiandho, Y., Afriani, F., Megiyo., 2017. Analisis Karakteristik Pori berdasarkan Pengolahan Citra menggunakan Wolfram Mathematica dan ImageJ. Palembang, AVoER IX Fakultas Teknik Universitas Sriwijaya.

Awitdrus, Rukmana, D. V., Farma, R., \& Iwantono, 2016. Pengaruh Waktu Perendaman dalam Pembuatan Karbon Aktif Cangkang Buah Ketapang dengan Pengaktifan Kimia Berbantuan Iradiasi Gelombang Mikro. Komunikasi Fisika Indonesia, pp. 870-875.

Du, H., Shin, J., \& Lee, S., 2005. Study on porosity of plasma-sprayed coatings by digital image analysis method. Journal of thermal spray technology, 14, pp. 453-461.

Hidayat, A., Alfitri, N., Hendrick, Ramiati., \& Bahtiar, B., 2013. Aplikasi pengolahan citra mikroskop untuk pendeteksi formalin pada tahu menggunakan kamera CCD (Charge Couple Device). Padang, Politeknik Negeri Padang.

Hendra, D. \& Darmawan, S., 2007. Sifat Arang Aktif dari Tempurung Kemiri. Forest Product Research, 86, pp. 1-18.

IUPAC, 1972. Manual of Symbols and Terminology for Physicochemichal quantities and Units. Butterworths, London.

Jagtoyen, M. \& Derbyshire, F., 1998. Activated Carbon from Yellow Poplar and White Oak by $\mathrm{H}_{3} \mathrm{PO}_{4}$ Activation. Carbon, 36, pp. 1085-1097.

Jambhekar, N., 2011. Red Blood Classification Using Image Processing. Science Research, 3, pp. 151-154.
Kwaghger, A. \& Ibrahim, J. S., 2013. Optimization of Condition for the Preparation of Activated Carbon from Mango Nuts using $\mathrm{HCl}$. American Journal of Engineering Research, 2(7), pp. 74-85.

Megiyo, Aldila, H., Afriani, F., Mahardika, R. G., \& Enggiwanto, S., 2017. Sintesis Karbon Aktif Tempurung Ketapang (Terminalia Catappa) sebagai Adsorben Minyak Jelantah. Surakarta, SNFA Universitas Sebelas Maret.

Moradi, A., Pramanik, S., Ataollahi, F., Kamarul, T., \& Murphy, B., 2014. Archimedes revisited: computer assisted micro-volumetric modification of the liquid displacement method for porosity measurement of highly porous light materials. Analytical Methods, pp. 43964401.

Goodman, P., Li, H., Gao, Y., Lu, Y., StengerSmith, J., \& Redepenning, J., 2012. Preparation and Characterization of High Surface Area, High Porosity Carbon Monoliths from Pyrolyzed Bovine Bone and their Performance as Supercapacitor Electrodes. Carbon, 55, pp. 291-298.

Rifano, R., 2014. Aplikasi ImageJ untuk menghitung perubahan luas inti eritrosit bebek akibat larutan hipotonis. IPB, Bandung.

Surest, A. H., Permana, I., \& Wibisono, R. G., 2010. Pembuatan Karbon Aktif dari Cangkang Biji Ketapang. Jurnal Teknik Kimia, 17, pp. 1-11.

Tiandho, Y., 2017. Analisis Kuantitatif Pori Berdasarkan Pengolahan Citra Menggunakan Wolfram Mathematica. Kumpulan Jurnal Ilmu Komputer, 4, pp. 15-23. 